\title{
ASSURANCE MAGAZINE,
}

AND

\section{J OURNAL}

OF THE

\section{INSTITUTE OF ACTUARIES.}

On the Rates of Premium required to provide certain Periodical Returns to the Assured. By Roвert Tucker, Esq., Actuary to the Pelican Life Insurance Company, and one of the VicePresidents of the Institute of Actuaries.

[Read before the Institute the 28th Jannary, 1861, and printed by order of the Council.]

A WELL-KNOWN contributor to the Assurance Magazine has drawn attention, at pp. 167 and 168 of the Number for April, 1859 , to " the incongruity existing between the rates of premium charged at certain ages on bonus policies, and the benefits to which they entitle the holder."

This question, "H. A. S." remarks, " hardly meets with the consideration it deserves among Actuaries." It has, nevertheless, not been altogether lost sight of ; for, so far back as the year 1851, Mr. Jellicoe noticed this "incongruity"; * and, so recently as the month of March, 1857, a paper was read before the Institute of Actuaries by Mr. Sprague, and published in the July Number of the Journal for that year, "On certain methods of dividing the surplus among the assured in a Life Assurance Company, and on the rates of premium that should be charged to render them equitable." In this paper various plans are investigated and examples

* See that gentleman's paper on the determination and distribution of surplus, vol. i., p. 161 ; also his paper on the conditions which give rise to surplus in Life Assurance Companies, and on the amount of return or "bonus" which such conditions justify, vol. ì., p. 333 .

VOL. IX. 
given-amongst them a formula almost identical with that by "H. A. S."

I propose to discuss this subject a little more in detail, and to introduce illustrations of some of the plans adopted by Assurance Institutions for the distribution of what, as it appears to me, cannot with propriety, in all cases, be called their surplus profits, but which may be designated as periodical returns made to the assured.

The example given in the letter referred to supposes a reversionary bonus of $\mathrm{P}$ per $£ 1$ per annum declared every $t$ years, which is added to the principal sum and forms the capital upon which the next bonus is computed, and so on.

The sum insured being $£ 1$, the annual bonus for the first period is $\mathbf{P}=\mathrm{B}_{1}$; for the second period $\mathrm{P}(1+t \mathrm{P})=\mathrm{B}_{2}$; for the third period $\mathrm{P}(1+t \mathrm{P})^{2}=\mathrm{B}_{3}$; and, generally, for the $n$th period $\mathbf{P}(1+t \mathbf{P})^{n-1}=\mathbf{B}_{n^{*}}$. Whence, by the ordinary commutation tables, the annual premium for such a benefit at age $x$ is-

$$
\frac{\mathrm{M}_{x}+\mathrm{B}_{1} \mathrm{R}_{x}+\left(\mathrm{B}_{2}-\mathrm{B}_{1}\right) \mathrm{R}_{x+t}+\left(\mathrm{B}_{3}-\mathrm{B}_{2}\right) \mathrm{R}_{x+2 t}+\& c .}{\mathrm{N}_{x-1}} \text {. . }
$$

If we substitute for $B_{1}, B_{2}, B_{3}$, \&c., their values, we have-

$$
\begin{aligned}
& \mathrm{B}_{1}=\mathrm{P}, \\
& \mathrm{B}_{2}-\mathrm{B}_{1}=\mathrm{P}(1+t \mathrm{P})-\mathrm{P}=t \mathrm{P}^{2}, \\
& \mathrm{~B}_{3}-\mathrm{B}_{2}=\mathrm{P}(1+t \mathrm{P})^{2}-\mathrm{P}(1+t \mathrm{P})=t \mathrm{P}^{2}(1+t \mathrm{P}), \\
& \mathrm{B}_{4}-\mathrm{B}_{3}=\mathrm{P}(1+t \mathrm{P})^{3}-\mathrm{P}(1+t \mathrm{P})^{2}=t \mathrm{P}^{2}(1+t \mathrm{P})^{2}, \\
& \quad \text { \&c. }=\& \mathrm{c} . ;
\end{aligned}
$$

and by dividing the annual premium into two parts, we obtain for the sum assured-

and for the bonus-

$$
\frac{\mathrm{M}_{x}}{\mathrm{~N}_{x-1}}
$$

$$
\frac{\mathrm{PR}_{x}+t \mathrm{P}^{2} \cdot\left\{\mathrm{R}_{x+t}+(1+t \mathrm{P}) \mathrm{R}_{x+2 t}+(1+t \mathrm{P})^{2} \mathrm{R}_{x+3 t}+8 \mathrm{c} .\right\}}{\mathrm{N}_{x-1}} .
$$

Mr. Sprague commences with $\mathbf{R}_{x+1}$, which, by the ordinary notation, is the value of an increasing assurance at age $(x+1)$ years, and implies that the additions are made according to the number of years of life completed by the assured, and not upon the number of premiums paid, which is the assumption in the other case. Subject to this alteration, the expression last obtained would be identical with that given by him.

The following examples are added by "H. A. S.," showing, according to the Carlisle 3 per cent. Table-1st, the annual premium to insure $£ 1,000$, at the ages stated; 2 nd, the annual 
premium required to meet the increasing benefit above described; and 3rd, the ratio of the first to the second.

\begin{tabular}{|c|c|c|c|}
\hline Age. & Premium for £1,000. & $\begin{array}{c}\text { Premium for \&1,000, } \\
\text { with Bonus. }\end{array}$ & Ratio. \\
\hline 20 & $14 \cdot 9358$ & $24 \cdot 3651$ & $1 \cdot 63$ \\
30 & $19 \cdot 5192$ & $29 \cdot 6399$ & $1 \cdot 52$ \\
40 & $25 \cdot 9932$ & $36 \cdot 8245$ & $1 \cdot 42$ \\
50 & $36 \cdot 2236$ & $47 \cdot 7889$ & $1 \cdot 32$ \\
60 & $57 \cdot 8955$ & $70 \cdot 1644$ & $1 \cdot 21$ \\
\hline
\end{tabular}

It is then noticed that if an addition of 30 per cent. were made to the ordinary premium, the entrants at age 50 " get a reasonable equivalent for their payments," whilst at other ages the benefits are greatly in favour of the younger lives. It is worthy of remark that those who advocate a constant addition to the net premium, in preference to a percentage on it, may here obtain a confirmation of their views; for it is observable that an addition of $\$ 10$ to the annual premium, without bonus, would very nearly provide for this reversionary bonus of £l5 per annum, with its accumulations.

If we make the comparison by the Northampton 3 per cent. Table - which, perhaps, more correctly represents the premiums charged by Offices adopting this mode of apportionment-the following table shows that the inequality above noticed nearly disappears. It also proves that members entering at the earlier ages of life do not contribute unduly in the shape of premium, as has been often alleged, when the ultimate benefit insured to them is taken into account.

\begin{tabular}{|c|c|c|c|}
\hline Age. & Preminm for £1,000. & $\begin{array}{c}\text { Premium for £1,000. } \\
\text { with Bonus. }\end{array}$ & Batio. \\
\hline 20 & $21 \cdot 794$ & $24 \cdot 365$ & $1 \cdot 12$ \\
30 & $26 \cdot 672$ & $29 \cdot 640$ & $1 \cdot 11$ \\
40 & $33 \cdot 975$ & $36 \cdot 825$ & $1 \cdot 08$ \\
50 & $45 \cdot 301$ & $47 \cdot 789$ & $1 \cdot 05$ \\
60 & $63 \cdot 661$ & $70 \cdot 164$ & $1 \cdot 10$ \\
\hline
\end{tabular}

In order to obtain a practical result from a comparison of our theoretical conclusions with the bonuses prevailing according to the practice of Assurance Offices in their declarations of profit, it is necessary in our illustrations to endeavour to adapt them to such practice. For instance, the reversionary addition of $P$ per $£ 1$ per annum $=B_{1}$ does not usually date from the commencement of the 
assurance, unless the life assured be living at the end of the first period of $t$ years; in like manner the subsequent annual increments $B_{2}-B_{1}, B_{3}-B_{2}$, \&c., do not vest unless the assured be living at the end of $2 t, 3 t$, \&c., years respectively. Thus, in fact, the assured has an interval bonus at the same rate as that he was entitled to on completing the last period of $t$ years.

The value, therefore, of the periodical additions, and of the prospective or interim bonuses, will be

$$
\begin{gathered}
t \text { P. } \mathrm{M}_{x+t-t}+\mathrm{P} \cdot \mathrm{R}_{x+t}+\left(\mathrm{B}_{2}-\mathrm{B}_{1}\right) \cdot\left(t \mathrm{M}_{x+2 t}+\mathrm{R}_{x+2 t}\right)+ \\
\left(\mathrm{B}_{3}-\mathrm{B}_{2}\right) \cdot\left(t \mathrm{M}_{x+3 t}+\mathrm{R}_{x+3 t}\right)+8 \mathrm{cc} . ;
\end{gathered}
$$

and the annual premium for the whole benefit

$$
\frac{\mathrm{M}_{x}+t \mathrm{P} \cdot \mathrm{M}_{x+t}+\mathrm{P} \cdot \mathbf{R}_{x+t}+\left(\mathbf{B}_{2}-\mathbf{B}_{1}\right) \cdot\left(t \mathrm{M}_{x+2 t}+\mathbf{R}_{x+2 t}\right)+\& \mathrm{cc} .}{\mathrm{N}_{x-1}} \text {. }
$$

After the expiration of $t$ years, a bonus of $P$ per $\& 1$ per annum being added for every future premium paid, the value of these additions is evidently P. $\mathbf{R}_{x+t}$; and the values of the subsequent increments are $\left(\mathbf{B}_{2}-\mathbf{B}_{1}\right) \cdot \mathbf{R}_{x+2 t},\left(\mathbf{B}_{3}-\mathbf{B}_{2}\right) \mathbf{R}_{x+3 t}$, \&c.

This alteration will not materially affect the results already given, and, as the compatations are somewhat laborious, it seems scarcely necessary to ascertain the exact difference at the ages enumerated.

In some Offices the practice of paying bonus upon bonus does not exist, the additions being made upon the original sum assured only. Suppose these additions to be uniform, and at the same rate as before, then $B_{1}=B_{2}=B_{3}$, \&c. $=P$, and the last expression becomes-

$$
\frac{\mathrm{M}_{x}+t \mathrm{PM}_{x+t}+\mathrm{PR}_{x+t}}{\mathrm{~N}_{x-1}} \text {. . . . . . . . }
$$

Here the assured has an interval bonus after surviving the first $t$ years.

When the bonus is declared at each period of $t$ years, and no addition is made in the event of death occurring between any two periods of division, the annual premium will be-

$$
\frac{\mathrm{M}_{x}+t \mathrm{P}\left(\mathrm{M}_{x+t}+\mathrm{M}_{x+2 t}+\mathrm{M}_{x+3 t}+\& \mathrm{c} .\right)}{\mathrm{N}_{x-1}}
$$

and when each periodical bonus is reckoned from the date of the policy, and an addition is made at the uniform rate when death occurs between two periods of division for the number of years so completed, the annual premium will be- 


$$
\frac{\mathrm{M}_{x}+t \mathrm{PM}_{x+t}+\mathrm{P} . \mathrm{R}_{x+t}+t \mathrm{P}\left(\mathrm{M}_{x+2 t}+2 \mathrm{M}_{x+3 t}+3 \mathrm{M}_{x+4 t}+\& \mathrm{c} .\right)}{\mathrm{N}_{x-1}}
$$

This assumes that no bonus is allowed if death take place before the expiration of the first period of $t$ years.

If we suppose no prospective bonus to be insured, but an uniform sum of $t \mathrm{P}$ added every $t$ years from the commencement, the premium will be-

$$
\frac{\mathrm{M}_{x}+t \mathrm{P}\left(\mathrm{M}_{x+t}+2 \mathrm{M}_{x+2 t}+3 \mathrm{M}_{x+3 t}+\& \mathrm{c} .\right)}{\mathrm{N}_{x-1}} \text {..... }
$$

which is also given by Mr. Sprague.

I now propose to add some examples of the premiums deduced from the formulæ (3), (4), and (5), according to the Carlisle 3 per cent. Table.

\section{Equation (3).}

Sum Assured, $£ 1,000 ;$ Bonus, $£ 1.10$ s. per cent. per annum for life,

\begin{tabular}{|c|c|c|c|}
\hline \multirow{3}{*}{ Age } & \multicolumn{3}{|c|}{ 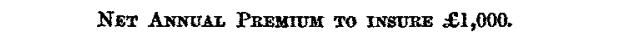 } \\
\hline & \multicolumn{2}{|c|}{ WTHOUT BoNDs. } & \multirow{2}{*}{$\begin{array}{c}\text { Wirh Bonus. } \\
\text { Carlisle. }\end{array}$} \\
\hline & Carlisle. & Northanpton. & \\
\hline $\begin{array}{l}20 \\
30 \\
40 \\
50 \\
60\end{array}$ & $\begin{array}{l}14 \cdot 9358 \\
19 \cdot 5192 \\
25 \cdot 9932 \\
36 \cdot 2236 \\
57 \cdot 8955\end{array}$ & $\begin{array}{l}21 \cdot 794 \\
26 \cdot 672 \\
33 \cdot 975 \\
45 \cdot 301 \\
63 \cdot 661\end{array}$ & $\begin{array}{l}21 \cdot 841 \\
27 \cdot 292 \\
34 \cdot 703 \\
45 \cdot 991 \\
68-383\end{array}$ \\
\hline
\end{tabular}
subject to the assured living 5 years from the date of entrance.

From this example it appears that annual premiums computed according to the Northampton 3 per cent. Table will just provide an addition to the sum assured of $\mathfrak{E} 1$. $10 s$. per cent. per annum, at least, up to the age of 50 .

EqUaTton (4).

Sum Assured, £,1000; Bonus, $£ 75$; added every 5 years.

\begin{tabular}{|c|c|}
\hline Age. & Annual Premium. \\
\hline 20 & $21 \cdot 2398$ \\
30 & 265262 \\
40 & 337082 \\
50 & $44 \cdot 5876$ \\
60 & $66^{*} 4635$ \\
\hline
\end{tabular}

The difference between these premiums and those resulting from equation (3) being inconsiderable, shows how very small is the value of the prospective or interim bonus. 
Equation (5).

Sum Assured, £1,000; Bonus, £1. 10s. per cent. per annum, reckoned from the date of policy, every 10 years, subject to the assured living 10 years; Prospective Bonus, £1. 10s. per cent. per annum.

\begin{tabular}{|c|c|}
\hline Age. & Annual Premium. \\
\hline 20 & $30 \cdot 380$ \\
30 & $34 \cdot 662$ \\
40 & $40 \cdot 420$ \\
50 & $49 \cdot 394$ \\
60 & $68 \cdot 995$ \\
\hline
\end{tabular}

These premiums show, still more forcibly, the advantages given to younger members when the bonuses date from the commencement of the policy.

The following examples from equations 3 and 5 are added, showing, according to the Carlisle 4 per cent. Table-

1. The Annual Premium to insure $£ 1,000$ at Death, with Addition of $£ 1, £ 1.10$ s., or £2 per Cent. per Annum every Five Years ; and a Prospective or Interim Bonus at the same Rate in each case.

\begin{tabular}{|c|c|c|c|c|}
\hline \multirow{3}{*}{ Age. } & \multicolumn{4}{|c|}{ ANnoar Prentem, } \\
\hline & \multirow{2}{*}{$\begin{array}{l}\text { WithodT } \\
\text { BonUs. }\end{array}$} & \multicolumn{3}{|c|}{ Wry Bonus of } \\
\hline & & $\begin{array}{l}\text { El per Cent. } \\
\text { per Annum. }\end{array}$ & $\begin{array}{l}\text { 21. 10s. per Cent. } \\
\text { per Annum. }\end{array}$ & $\begin{array}{l}\text { \&2 per Cent. } \\
\text { per Annum. }\end{array}$ \\
\hline $\begin{array}{l}20 \\
30 \\
40 \\
50 \\
60\end{array}$ & $\begin{array}{l}13 \cdot 18 \\
17 \cdot 55 \\
23 \cdot 75 \\
33 \cdot 64 \\
55 \cdot 31\end{array}$ & $\begin{array}{l}16 \cdot 773 \\
21 \cdot 744 \\
28 \cdot 626 \\
39 \cdot 327 \\
61 \cdot 607\end{array}$ & $\begin{array}{l}18 \cdot 569 \\
23 \cdot 842 \\
31 \cdot 063 \\
42 \cdot 170 \\
64 \cdot 756\end{array}$ & $\begin{array}{l}20 \cdot 366 \\
25 \cdot 939 \\
33 \cdot 501 \\
45 \cdot 013 \\
67 \cdot 905\end{array}$ \\
\hline
\end{tabular}

2. The Annual Premium to insure $£ 1,000$ at Death, with Addition of £1, £1. 10s., or £2 per Cent. per Annum every Ten Years, caleulated from the Date of the Policy; and a Prospective or Interim Bonus at the same Rate in each case.

\begin{tabular}{|c|c|c|c|c|}
\hline \multirow{3}{*}{ Age. } & \multicolumn{4}{|c|}{ ANndax. Premien. } \\
\hline & \multirow{2}{*}{$\begin{array}{l}\text { WITHodT } \\
\text { Bonts. }\end{array}$} & \multicolumn{3}{|c|}{ Wrth Bonus of } \\
\hline & & $\begin{array}{l}\text { \&l per Cent. } \\
\text { per Annum. }\end{array}$ & $\begin{array}{l}\text { 21. 10s. per Cent. } \\
\text { per Annum. }\end{array}$ & $\begin{array}{l}\text { c2 per Cent. } \\
\text { per Annum. }\end{array}$ \\
\hline $\begin{array}{l}20 \\
30 \\
40 \\
50 \\
60\end{array}$ & $\begin{array}{l}13 \cdot 18 \\
17 \cdot 55 \\
23 \cdot 75 \\
33 \cdot 64 \\
55 \cdot 31\end{array}$ & $\begin{array}{l}20 \cdot 773 \\
25 \cdot 359 \\
31 \cdot 546 \\
41 \cdot 081 \\
61 \cdot 792\end{array}$ & $\begin{array}{l}24 \cdot 569 \\
29 \cdot 264 \\
35 \cdot 444 \\
44 \cdot 801 \\
65 \cdot 033\end{array}$ & $\begin{array}{l}28 \cdot 365 \\
33 \cdot 168 \\
39 \cdot 342 \\
48 \cdot 521 \\
68 \cdot 274\end{array}$ \\
\hline
\end{tabular}


Hitherto we have considered only the ratio which the annual premium for an assurance, with bonus additions, at a given rate bears to the net premium for the same assurance without bonus. Let us now examine the effect of a reduction of premium after a given number of years.

Suppose $\pi_{x}$ to be the annual premium to insure $£ 1$ at age $x$, and $\rho$ the reduction per cent. after $t$ years-

$$
\begin{gathered}
\text { then } \pi_{x}\left(1+t_{t-1\rceil} a_{x}+\overline{1-\rho_{\rceil^{t-1}}} a_{x}\right)=\mathrm{A}_{x}, \\
\text { whence } \pi_{x}=\frac{\mathrm{A}_{x}}{1+{ }_{t-1\rceil} a_{x}+\overline{1-\rho} a_{\rceil^{t-1}}}=\frac{\mathrm{A}_{x}}{\left.1+a_{x}-\rho a_{x}\right\rceil^{t-1}} .
\end{gathered}
$$

If $\pi_{x}^{\prime}$ be the premium actually paid, $\pi_{x}^{\prime}=(1+\kappa) \pi_{x} ; \pi_{x}$ being the net premium and $\boldsymbol{\kappa}$ the addition to it;

$$
\begin{aligned}
& \text { whence } \rho \underset{T_{x}}{\prod^{t-1}}=1+a_{x}-\frac{A_{x}}{\pi_{x}^{\prime}}=\left(1+a_{x}\right) \cdot\left(1-\frac{1}{1+\kappa}\right)=\frac{\kappa\left(1+a_{x}\right)}{1+\kappa} \text {, } \\
& \text { and } \rho=\frac{\kappa\left(1+a_{x}\right)}{(1+\kappa) a_{x{ }^{\prime} t-1}} \text {. }
\end{aligned}
$$

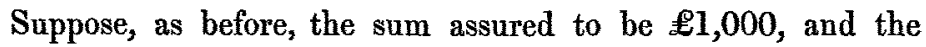
reduction of premium to be 50 per cent. after 5 years, the following examples show, according to the Carlisle 3 per cent. Table, the

\begin{tabular}{|c|c|c|c|c|c|}
\hline Age. & $\begin{array}{c}\begin{array}{c}\text { Carlisle, } \\
\text { without reduction. } \\
1 .\end{array} \\
1 .\end{array}$ & $\begin{array}{c}\text { Carlisle, } \\
\text { with reduction of } \\
50 \text { per cent. } \\
\text { after five years. } \\
\mathbf{2 .}\end{array}$ & $\begin{array}{c}\text { Northampton, } \\
\text { without reduetion. } \\
3 .\end{array}$ & 1 to 2. & 3 to 2. \\
\hline $\begin{array}{l}20 \\
30 \\
40 \\
50 \\
60\end{array}$ & $\begin{array}{l}14 \cdot 936 \\
19 \cdot 519 \\
25 \cdot 993 \\
36 \cdot 224 \\
57 \cdot 895\end{array}$ & $\begin{array}{l}24+796 \\
31 \cdot 868 \\
41 \cdot 483 \\
55 \cdot 736 \\
83 \cdot 706\end{array}$ & $\begin{array}{l}21 \cdot 794 \\
26 \cdot 672 \\
33 \cdot 975 \\
45 \cdot 301 \\
63 \cdot 661\end{array}$ & $\begin{array}{l}1 \cdot 66 \\
1 \cdot 63 \\
1 \cdot 59 \\
1 \cdot 54 \\
1 \cdot 44\end{array}$ & $\begin{array}{l}1 \cdot 14 \\
1 \cdot 19 \\
1 \cdot 22 \\
1 \cdot 23 \\
1 \cdot 31\end{array}$ \\
\hline
\end{tabular}
ratio which such premiums bear to the net premium payable during life, according to the Carlisle and Northampton Tables respectively.

Again : suppose the reduction to be 80 per cent. after 7 years, and we obtain the following results:- 


\begin{tabular}{|c|c|c|c|}
\hline Age. & $\begin{array}{c}\text { Annual Premium, } \\
\text { with 80 per cent. } \\
\text { rellution after seren } \\
\text { years. }\end{array}$ & Carlisle. & Northampton. \\
\hline 20 & $35 \cdot 420$ & $2 \cdot 37$ & 1.62 \\
30 & $44 \cdot 105$ & $2 \cdot 26$ & 1.65 \\
40 & 55.085 & $2 \cdot 12$ & 1.62 \\
50 & 69.462 & 1.92 & $1 \cdot 53$ \\
60 & 96.058 & $1 \cdot 66$ & $1 \cdot 51$ \\
\hline
\end{tabular}

It will be seen that, while the values are greatly disproportionate at 20 and 60 , they are more uniform at the intermediate ages; and that at all ages, particularly in the last examples, the premiums required are so much in excess of those usually charged, that it is natural to ask, not only how such reductions can be made, but how they can be maintained for any length of time.

Let us take another view of this case, and let us suppose an Office to charge certain rates of premium, with an implied obligation to reduce the same by 50 per cent. after 5 years, and certain other rates with a reduction of 80 per cent. after 7 years; the following examples show the single premiums corresponding to these rates, also the single premium according to the Carlisle 4 per cent. Table, which is considered to represent very nearly the net value, or prime cost, of an assurance for life. On comparing columns 3 and 5 with 6 , it appears that the values are greater in 3 than in 6, except at the advanced ages, and that in 5 they are less at all ages. The premiums in column 2 are somewhat higher up to the age of 40 than are usually charged.

\begin{tabular}{|c|c|c|c|c|c|}
\hline Age- & $\begin{array}{c}2 . \\
\text { Annnal } \\
\text { Preminm } \\
\text { per centin with } \\
\text { reduction of } \\
50 \text { per cent. } \\
\text { after five } \\
\text { years }\end{array}$ & $\begin{array}{c}\mathbf{3 .} \\
\text { Corresponding } \\
\text { Single } \\
\text { Premium. }\end{array}$ & $\begin{array}{c}4 \\
\text { Annual } \\
\text { Premiam } \\
\text { per cent, with } \\
\text { reduction of } \\
\text { 80 per cent. } \\
\text { after seven } \\
\text { years. }\end{array}$ & $\begin{array}{c}5 . \\
\text { Corresponding } \\
\text { Single } \\
\text { Premium. }\end{array}$ & $\begin{array}{c}6 . \\
\text { Single } \\
\text { Preminum } \\
\text { per cent, } \\
\text { Carlisle } \\
\text { 4 per cent. }\end{array}$ \\
\hline $\begin{array}{l}20 \\
30 \\
40 \\
50 \\
60\end{array}$ & $\begin{array}{l}2 \cdot 25 \\
2 \cdot 75 \\
3 \cdot 50 \\
4 \cdot 50 \\
6 \cdot 50\end{array}$ & $\begin{array}{l}30 \cdot 766 \\
34 \cdot 625 \\
39 \cdot 788 \\
44 \cdot 753 \\
51 \cdot 662\end{array}$ & $\begin{array}{l}2 \cdot 50 \\
3 \cdot 00 \\
3 \cdot 75 \\
5 \cdot 25 \\
7 \cdot 50\end{array}$ & $\begin{array}{l}23 \cdot 925 \\
27 \cdot 293 \\
32 \cdot 104 \\
41 \cdot 895 \\
51 \cdot 945\end{array}$ & $\begin{array}{l}25 \cdot 532 \\
31 \cdot 338 \\
38 \cdot 178 \\
46 \cdot 658 \\
58 \cdot 987\end{array}$ \\
\hline
\end{tabular}

The two plans of augmenting the sum originally assured by an annual percentage at stated periods, and of materially diminishing the annual premium after a certain number of years, are, I think, held most in favour by the public-probably because they are more clearly defined, and therefore better understood and 
appreciated, than any of the other modes of division adopted by Assurance Companies. For the same reason, it may be easier to estimate the value of these periodical additions and annual reductions than the values under any other plan, and thus to point out what the assured gain over and above their contributions, for these differences really constitute the actual bonuses realized, and not that portion of them for which a consideration is paid in the original contract.

It is the custom with some Offices to apportion their profits according to the amount received upon each policy, less its value at the period of division. This difference is called the "proportional bonns;" and the method of determining the sum in ready money to be allotted to each policy, is, to compare the surplus to be divided with the total amount of these differences-that is, with the total in the proportional bonus column. Thus, if the divisible surplus is found to be 30 per cent. of the total amount of "proportional bonus," the ready-money bonus upon each policy will, in like manner, be 30 per cent. of the "proportional bonus" appertaining thereto-or, expressed in official language, the common multiplier will be $\cdot \mathbf{3}$.

If $s^{t}$ represent the amount of $\$ 1$ per annum in $t$ years, the "proportional bonus" will then be-

$$
\begin{aligned}
& \quad\left(s^{t+1}-1\right) \pi_{x}^{\prime}-\left(\pi_{x+t}^{\prime}-\pi_{x}^{\prime}\right) \cdot\left(1+a_{x+t}^{\prime}\right) ; \\
& \text { or, }\left(s^{t+1}-1\right) \pi_{x}^{\prime}-\mathbf{A}_{x+t}^{\prime}+\pi_{x}^{\prime \prime} \cdot\left(1+a_{x+t}^{\prime}\right) ; \\
& \text { or, }\left(s^{t+1}+a_{x+t}^{\prime}\right) \pi_{x}^{\prime}-\mathbf{A}_{x+t}^{\prime} .
\end{aligned}
$$

At the second investigation, the premium is calculated according to the age of the life assured at the previous valuation; and not only upon the sum originally assured, but also upon the addition then made to the policy. So that the "proportional bonus" at the end of $2 t$ years will be

$$
\left\{\left(s^{t+1}+a_{x+2 t}^{\prime}\right) \pi_{x+t}^{\prime}-\mathrm{A}_{x+2 t}^{\prime}\right\} \cdot\left(1+\bar{B}_{1}^{\prime}\right),
$$

$\$ 1$ being the amount insured, and $B_{1}^{\prime}$ the first bonus.

At the end of $3 t$ years, the "proportional bonus" will be

$$
\left\{\left(s^{t+1}+a_{x+3 t}^{\prime}\right) \pi_{x+2 t}^{\prime}-A_{x+3 t}^{\prime}\right\} \cdot\left(1+B_{1}^{\prime}+B_{2}^{\prime}\right) \text {; }
$$

and, generally, at the end of $n t$ years the "proportional bonus" will be

$$
\left\{\left(s^{t+1}+a_{x+n i}^{\prime}\right) \cdot \pi_{x+\overline{n-1}, t}^{\prime}-\mathrm{A}_{x+n t}^{\prime}\right\} \cdot\left(1+\mathrm{B}_{1}^{\prime}+\mathrm{B}_{2}^{\prime}+\mathrm{B}_{3}^{\prime} \ldots \mathrm{B}_{n-1}^{\prime}\right) .
$$

It does not appear that the bonuses resulting from this mode of apportionment follow any order of progression, and therefore it 
will be necessary, in assuming a common multiplier, to calculate the bonus at each period of division, if we wish to ascertain the corresponding premium.

The following table shows, according to the Northampton 3 per cent. premiums, the bonus accruing to a policy for $£ 1,000$ at the end of $5,10,15, \& c$. , years, assuming the "divisible surplus" to be 25 per cent. of the " proportional bonus."

\begin{tabular}{|c|c|c|c|c|c|c|}
\hline $\begin{array}{c}\text { No. } \\
\text { of } \\
\text { Years }\end{array}$ & \multicolumn{7}{|c|}{ Ages } & $\begin{array}{c}\text { No. } \\
\text { of } \\
\text { Years. }\end{array}$ \\
\hline & 20. & 30. & 40. & 50. & 60. & \\
5 & $42 \cdot 703$ & $44 \cdot 874$ & $49 \cdot 323$ & $58 \cdot 830$ & $73 \cdot 524$ & 5 \\
10 & $45 \cdot 775$ & $48 \cdot 134$ & $54 \cdot 925$ & $68 \cdot 606$ & $89 \cdot 948$ & 10 \\
15 & $48 \cdot 899$ & $53 \cdot 911$ & $64 \cdot 953$ & $81 \cdot 766$ & $124 \cdot 011$ & 15 \\
20 & $52 \cdot 396$ & $60 \cdot 034$ & $75 \cdot 758$ & $101 \cdot 316$ & $184 \cdot 734$ & 20 \\
25 & $58 \cdot 685$ & $70 \cdot 994$ & $90 \cdot 289$ & $139 \cdot 685$ & $305 \cdot 083$ & 25 \\
30 & $65 \cdot 349$ & $82 \cdot 804$ & $111 \cdot 877$ & $208 \cdot 082$ & $543 \cdot 335$ & 30 \\
35 & $77 \cdot 279$ & $98 \cdot 687$ & $154 \cdot 245$ & $343 \cdot 641$ & $747 \cdot 651$ & 35 \\
40 & $90 \cdot 134$ & $122 \cdot 283$ & 229772 & $612 \cdot 003$ & & 40 \\
45 & $107 \cdot 423$ & $168 \cdot 591$ & $379 \cdot 462$ & $842 \cdot 143$ & & 45 \\
50 & $133 \cdot 108$ & $251 \cdot 143$ & $675 \cdot 797$ & & & 50 \\
55 & $183 \cdot 517$ & $414 \cdot 755$ & $929 \cdot 927$ & & & 55 \\
60 & $273 \cdot 377$ & $733 \cdot 208$ & & & & 60 \\
65 & $451 \cdot 473$ & $\mathbf{1 0 1 4 \cdot 6 6 4}$ & & & & 65 \\
70 & $804 \cdot 045$ & & & & & 70 \\
75 & $1106 \cdot 402$ & & & & & 75 \\
\hline
\end{tabular}

If we measure the value of these benefits by the Carlisle 3 per cent. Table, and compare the corresponding annual premiums with the net premiums deduced from the Carlisle and Northampton 3 per cent. premiums respectively, without bonus, we obtain the following results :-

\begin{tabular}{|c|c|c|c|}
\hline \multirow{2}{*}{ Age. } & \multirow{2}{*}{$\begin{array}{l}\text { Preminm to } \\
\text { insure } \mathcal{E} 1,000, \\
\text { With Bonas. }\end{array}$} & \multicolumn{2}{|c|}{ Ratio to } \\
\hline & & Carlisle. & Northampton. \\
\hline $\begin{array}{l}20 \\
30 \\
40 \\
50 \\
60\end{array}$ & $\begin{array}{l}20 \cdot 814 \\
26 \cdot 495 \\
34 \cdot 452 \\
43 \cdot 660 \\
70 \cdot 833\end{array}$ & $\begin{array}{l}1 \cdot 39 \\
1 \cdot 36 \\
1 \cdot 33 \\
1 \cdot 31 \\
1 \cdot 22\end{array}$ & $\begin{array}{c}\cdot 955 \\
\cdot 993 \\
1 \cdot 01 \\
\cdot 964 \\
1 \cdot 11\end{array}$ \\
\hline
\end{tabular}

From which it appears that, according to the Carlisle 3 per cent. pure premiums, a loading of 39 per cent. at age 20 , and of 22 per cent. at age 60 , is necessary to secure these periodical additions; and that the Northampton 3 per cent. premium at age 20 is in excess about 5 per cent., and is deficient about 11 per cent. at 
age 60 , of the rates required for the same purpose. At 30 , 40 , and 50, the results, as in previous examples, exhibit more uniformity.

If the "proportional bonus" at each investigation were reckoned upon the "sum assured only," and not upon "the sum assured and previous additions," then every person of the same age would receive the same rate of bonus. This is evident from the general expression-

$$
\left(s^{t+1}+a_{x+n t}^{\prime}\right) \pi_{x+\overline{n-1} t}^{\prime}-A_{x+n t}^{\prime} .
$$

The same relative result, or nearly so, would be obtained from some rates of premium by making the "proportional bonus" depend upon the improved amount of the total number of premiums paid upon a policy, less the accumulation at the previous valuationthat is, by dedueing the "proportional bonus" from the expression

$$
\left(s^{n t+1}-s^{\bar{n}-1, t+1}\right) \pi_{x}^{\prime} .
$$

Another mode of making periodical returns to the assured, and the last which I propose to notice, is that of adding at each valuation a sum to the policy bearing a certain proportion to the number of premiums paid upon it.

The annual premium for an insurance with such benefits will be-

$$
\begin{aligned}
\pi_{x} & =\frac{\mathrm{M}_{x}+t \phi \pi_{x} \cdot\left(\mathrm{M}_{x+t}+2 \mathrm{M}_{x+3 t}+3 \mathrm{M}_{x+3 t}+\& \mathrm{c} .\right)}{\mathrm{N}_{x-1}}, \\
& =\frac{\mathrm{M}_{x}}{\mathrm{~N}_{x-1}-t \phi\left(\mathrm{M}_{x+t}+2 \mathrm{M}_{x+2 t}+3 \mathrm{M}_{x+3 t}+\& \mathrm{c} .\right)}
\end{aligned}
$$

If we take $t=5$, and suppose the addition at each quinquennial period to be equal to 20 per cent. per annum on the premiums paid, then $\phi=\cdot 2$ and $t \phi=1$; whence $\pi_{x}$ becomes

$$
\frac{\mathrm{M}_{x}}{\mathrm{~N}_{x-1}-\left(\mathrm{M}_{x+5}+2 \mathrm{M}_{x+10}+3 \mathrm{M}_{x+15}-\& \mathrm{c} .\right)} \text {. }
$$

The following examples are added, showing the net annual premium to insure $\mathfrak{E} 1,000$ at death according to the Carlisle 3 per cent. Table, with an addition of one year's premium at the end of 5, two years' premium at the end of 10, three years' premium at the end of 15 years, and so on; also the ratio which these premiums bear to the Carlisle and Northampton 3 per cent. Tables respectively, without addition. 


\begin{tabular}{|c|c|c|c|}
\hline \multirow{3}{*}{ Age. } & \multirow{3}{*}{$\begin{array}{c}\text { Preminum to } \\
\text { insure } £ 1,000, \\
\text { with Bonus. }\end{array}$} & \multicolumn{2}{|c|}{ Ratio to } \\
\hline & & Carisisle. & thampton. \\
\hline & & \multicolumn{2}{|c|}{ Without Bonus. } \\
\hline 20 & $24 * 454$ & $1 \cdot 64$ & $1 \cdot 12$ \\
\hline $\mathbf{3 0}$ & $31 \cdot 271$ & $1 \cdot 60$ & $1 \cdot 17$ \\
\hline 40 & $39 \cdot 938$ & $1 \cdot 54$ & $1 \cdot 17$ \\
\hline 50 & $52 \cdot 135$ & $1 \cdot 44$ & $1 \cdot 15$ \\
\hline 60 & 76.807 & $1 \cdot 33$ & $1 \cdot 21$ \\
\hline
\end{tabular}

It is scarcely necessary to remark, that the examples given in this paper may be readily worked out from the published tables of annuities and assurances-immediate, deferred, and increasing. For instance, the formula last given,

$$
\pi_{x}=\frac{M_{x}}{N_{x-1}-\left(M_{x+5}+2 M_{x+10}+3 M_{x+15}+\& c_{1}\right)},
$$

may be put under the form-

$$
\begin{aligned}
& \pi_{x}=\frac{\frac{\mathrm{M}_{x}}{\mathrm{D}_{x}}}{\frac{\mathrm{N}_{x-1}}{\mathrm{D}_{x}}-\frac{\mathrm{M}_{x+5}+2 \mathrm{M}_{x+10}+\& \mathrm{c} .}{\mathrm{D}_{x}}}, \\
& =\frac{\mathrm{A}_{x}}{1+a_{x}-\left(\mathrm{A}_{7^{5}}+2 \mathrm{~A}_{x}+3 \mathrm{~A}_{x}+\& \mathrm{c} .\right)},
\end{aligned}
$$

and the results readily obtained from Mr. Thomson's Actuarial Tables 1 and 2 (single lives and single deaths). I have not thought it necessary to show the net preminms required to provide guaranteed bonuses. These are simply another name for so many deferred assurances, not entitling the policy-holders to participate in the profits of the Company.

On taking a general review of the "bonus question," one cannot help being impressed with the advantage of selecting the participating in preference to the non-participating plan of assurance. This is apparent, if we examine with attention the large bonuses declared by some Societies, and compare the premiums charged to their members with what they ought to pay to ensure such benefits. The public are not slow to perceive that, however low the nonparticipating rates of an Office may be, the immediate gain of an addition to the sum assured which a given payment would secure, when compared with the amount which the same annual sum would assure according to the participating rates of premium, is not so tempting as the ultimate prospect of a much larger addition. We accordingly find that most Offices now conduct their business 
on the principle of admitting their policy-holders to share in their profits.

Confining our observations to reversionary bonuses, and omitting all further consideration of the plan of making a large annual reduction in the first premium after a fixed period, which, although apparently very simple, has never received a satisfactory solution, we have seen that an addition of $\$ 1$. 10s. per cent. per annum, subject to the assured living 5 years, is the amount of bonus expected to accrue to members paying the Northampton 3 per cent. premium. This is without making any allowance for commission and charges of management. Against these items we may fairly set the various sources of profit realized by Assurance Companies-such as that arising from excess of interest over 3 per cent.-the rate upon which their calculations are usually basedprofit from lapsed and surrendered policies, from suspended mortality, \&c. \&c. Suppose these various elements of profit to be sufficient to sustain the working of an Assurance Company, and that a return is made to the policy-holders equal in value to the loading or addition to the net premium for the risk undertaken, it would appear that such a Company fulfils all that can be reasonably expected from it.

Since this paper was written, my attention has been called to Mr. Scratchley's Treatise on Life Assurance Societies, in which some remarks are made on the errors of the bonus system, and some formula are given in an appendix for estimating the value of a bonus.

It would have been an omission on my part not to have referred to the labours of so popular a writer as Mr. Scratchley. The only formula, however, in his work, bearing on the particular cases which I have introduced, is

$$
\frac{(\mu+1) \mathbf{M}_{x}+\cdot 02 \Sigma M_{x}}{N_{x}}
$$

the annual premium for an assurance with a guaranteed bonus of 2 per cent. per annum. The other formulæ appear to be illustrations of the author's peculiar views "As to Bonuses."

Whether, as Mr. Scratchley asserts, the only case in which the payment of a bonus to an assurer is really proper or desirable, is when he has paid up in Office premiums, with interest, the amount of his policy, be true or not, depends very much, I submit, on the rates of premium charged. Apart from this consideration, no 
satisfactory conclusion can be arrived at ; and the statement must be received as the mere expression of an individual opinion.*

The truth is, that the whole bonus system is a matter of agreement. The public are invited to pay certain premiums, manifestly higher than are necessary for the risks undertaken, and for which the assured are to receive certain periodical returns-not, be it observed, "guaranteed," but dependent on the success of the particular Office they have selected.

There is clearly nothing unfair in practice, nor unsound in principle, in such arrangement, provided the returns are made with a due regard to the premiums paid. That some plans are more attractive than others, without being really better, may be readily imagined; but that unfair means should be resorted to by respectable Offices to make them so is not so easily credited.

I confess I have read with regret Mr. Scratchley's assertion, that various respectable Offices have taken to declaring bonuses so large as to be obviously not justified by their financial condition nor consistent with security.

It is difficult to believe that any respectable Office, properly so called, would do anything of the kind; and it seems to me unjustifiable that so severe a censure should be passed upon various respectable Offices, when the author only produces one solitary example in support of his declaration, and this is given on the authority of an experienced actuary whose name is withheld.

The extent of the error committed when the premiums paid are represented as creating large profits, is pointed out by $\mathrm{Mr}$. Scratchley in a table showing the amount that a net annual premium of $\& 1$ will assure at the death of a person of any given age, or the amount to which an annuity due of $\mathrm{El}$ will accumulate by the end of the year of his death.

Mr. Scratchley appears to have committed the same error that some other writers have done, by treating these questions as identical. Professor De Morgan has shown, in the Companion to the British Almanack for 1842, that the answer to the first question is

$$
\begin{gathered}
\frac{\mathrm{N}_{x-1}}{\mathrm{M}_{x}}, \\
\text { or, } \frac{(1+r) \cdot(1+\mathrm{A})}{1-r \mathrm{~A}} ;
\end{gathered}
$$

* See, however, the remarks on this subject at page 163 of the paper in vol. $i$, already referred to. 
A being the value of a life annuity and $r$ the rate of interest; and that the answer to the second is

$$
\frac{a_{x+1}}{a_{x}}(1+r)+\frac{a_{x+2}}{a_{x}}(1+r)^{2}+\frac{a_{x+3}}{a_{x x}}(1+r)^{3}+\ldots
$$

$a_{x}$ denoting the number of persons living at any age $x$.

Mr. De Morgan also adds the following examples by the Northampton Table at 4 per cent., showing the average sums obtained in the two cases :-

\begin{tabular}{|c|c|c|c|c|c|}
\hline Age. & 1st Case. & 2nd Case. & Age. & 1st Case. & 2nd Case. \\
\hline 20 & $49 \cdot 4$ & $98 \cdot 3$ & 45 & $27 \cdot 2$ & $38 \cdot 0$ \\
25 & $44 \cdot 7$ & $82 \cdot 2$ & 50 & $23 \cdot 2$ & $30 \cdot 7$ \\
30 & $40 \cdot 2$ & $68 \cdot 6$ & 55 & $19 \cdot 7$ & $24 \cdot 5$ \\
35 & $35 \cdot 7$ & $56 \cdot 8$ & 60 & $17 \cdot 0$ & $19 \cdot 2$ \\
40 & $31 \cdot 3$ & $46 \cdot 7$ & & & \\
\hline
\end{tabular}

And Mr. Hardy enters into an elaborate investigation of the proper method of determining the amount of an annuity forborne and improved at interest during the existence of a given life, in a paper read before the Institute on the 26th January, 1857, and published in the April number of the Journal for that year, clearly demonstrating that the expressions above given are identical only when the annuity is forborne and improved for a term of years certain, or when money bears no interest-in fact, that one is the average of present values, the other of amounts. 